\title{
PENGEMBANGAN MODEL PEMBELAJARAN TEKS ANEKDOT DENGAN STAD DAN MAKE A MATCH PADA SISWA KELAS X SMA
}

\section{THE DEVELOPMENT OF ANECDOTE TEXT LEARNING MODEL WITH STAD AND MAKE A MATCH ON THE TENTH GRADE SENIOR HIGH SCHOOL STUDENTS}

\author{
Suharti \\ SMA Negeri 2 Samarinda \\ Pos-el: suharti914@ymail.com
}

*) Naskah masuk: 29 November 2018. Penyunting: Abd. Rahman, S.S. Suntingan I: 16 April 2019. Suntingan II: 6 Mei 2019.

\begin{abstract}
Abstrak
Pengembangan ini bertujuan untuk menghasilkan produk berupa buku model Pembelajaran Teks Anekdot dengan STAD dan Make A Match pada Siswa Kelas X SMA. Pengembangan pembelajaran digunakan untuk memudahkan guru dan siswa mengidentifikasi struktur teks anekdot. Metode pengembangan yang digunakan adalah (Research and Development/ $\mathrm{R} \& \mathrm{D})$ dengan pembelajaran model Dick \& Carey. Hasil pengembangan menunjukkan hasil sudah memenuhi standar setelah melalui validasi uji ahli materi, uji ahli bahasa, uji praktisi pendidikan, dan uji ahli media dengan perolehan nilai rata-rata 92 dan kriteria kualifikasi sangat layak/sangat baik. Hasil belajar siswa kelompok uji coba sangat baik dengan nilai pengetahuan individu, keterampilan individu, dan ketrerampilan kelompok rata-rata 96. Hasil belajar siswa kelompok uji lapangan sangat baik dengan nilai pengetahuan individu, keterampilan individu, dan ketrerampilan kelompok rata-rata 97. Nilai respon guru dan siswa diperoleh presentase $96 \%$, dengan kualifikasi sangat baik. Data dianalisis secara deskriptif kualitatif dan analisis statistik deskriptif. Berdasarkan temuan pengembangan, dapat disimpulkan bahwa pengembangan pembelajaran teks anekdot dengan Model STAD dan Make A Match pada Siswa Kelas X SMA dapat digunakan oleh guru dalam pembelajaran di kelas.
\end{abstract}

Kata Kunci: pembelajaran teks anekdot, STAD, make a match

\begin{abstract}
This development aims to create a product of anecdote learning model book based on STAD and Make A Match on the tenth grade senior high school students. It can be used to facilitate teachers and students to identify the structure of anecdote. It uses Research and Development/RED of Dick and Carey's learning model. The results show that it has fulfilled the standard validated by material expert test, linguist test, educational practitioner test, and media expert test with the average score of 92, very feasible/very good criteria. The students' learning outcomes of the experimental group are excellent with the average of individual cognitive, individual affective, and the group affective score of 96 . The students' learning outcomes of the field test group are excellent with the average of individual cognitive, individual affective, and group affective score of 97 . The percentage of teachers and students' response rate are $96 \%$, excellent qualifications. It applies qualitative descriptive and descriptive statistical analysis.
\end{abstract}


Based on the development findings, it can be concluded that the development of anecdote learning with STAD Model and Make A Match on the tenth grade senior high school students can be employed by teachers in the classroom learning.

Keywords: Anecdote Learning, STAD, Make A Match

\section{PENDAHULUAN}

Peraturan Pemerintah Nomor 19 Tahun 2005 tentang Standar Nasional Pendidikan sebagaimana telah diubah dengan Peraturan Pemerintah Nomor 32 Tahun 2013 tentang Perubahan atas Peraturan Pemerintah Nomor 19 Tahun 2005 tentang Standar Nasional Pendidikan. Setiap satuan pendidikan melakukan perencanaan pembelajaran, pelaksanaan proses pembelajaran serta penilaian proses pembelajaran untuk meningkatkan efisiensi dan efektivitas ketercapaian kompetensi lulusan (Kemendikbud, 2016).

Standar isi mencakup segala sesuatu yang terdiri atas berbagai aspek yang akan dicapai dan menjadi pengalaman belajar peserta didik. Aspek tersebut meliputi melakukan perencanaan dan persiapan pembelajaran sebelum melakukan pembelajaran di kelas, melaksanakan proses pembelajaran dengan mendampingi dan membantu siswa dalam melalui proses pembelajaran. Selanjutnya, melakukan penilaian terhadap hasil proses pembelajaran di kelas. Semua hal tersebut dilakukan oleh guru dan siswa untuk meningkatkan efisiensi dan efektivitas ketercapaian kompetensi lulusan.

Standar proses tercantum pada lampiran permendikbud nomor 22 Tahun 2016 tentang Standar Proses Pendidikan Dasar dan Menengah. Proses pembelajaran pada satuan pendidikan diselenggarakan secara interaktif, inspiratif, menyenangkan, menantang, memotivasi peserta didik untuk berpartisipasi aktif, serta memberikan ruang yang cukup bagi prakarsa, kreativitas, dan kemandirian sesuai dengan bakat, minat, dan perkembangan fisik serta psikologis peserta didik (Kemendikbud, 2016).

Pembelajaran insipiratif adalah pembelajaran yang mendorong dan mengajak siswa untuk mencari serta menemukan halhal baru yang inovatif. Pembelajaran yang menyenangkan adalah bila siswa dalam proses pembelajaran merasa dapat mengikuti dan menyelesaikan teks materi yang disampaikan. Pembelajaran yang menantang adalah siswa mempunyai keinginan untuk dapat menyelesaikan atau mencari solusi atas permasalahan yang ditemukan dalam proses pembelajaran.

Peran guru dalam mewujudkan standar isi dan standar proses adalah guru sebagai desainer atau perancang pembelajaran yang interaktif, inspiratif, menyenangkan, dan menantang. Guru sebagai fasillitator yakni berkenaan dengan peran guru pada saat melaksanakan interaksi belajar mengajar pada siswa di kelas. Guru sebagai fasilitator menempatkan diri sebagai salah satu sumber belajar dan memberikan arahan banyaknya sumber belajar lain yang ada di sekitar siswa. Guru sebagai evaluator mengenai pelaksanaan pembelajaran pada satuan pendidikan untuk mencapai Standar Kompetensi Lulusan (SKI).

Pembelajaran bahasa Indonesia saat ini berbasis pada teks. Seluruh materi menyajikan teks-teks yang cukup panjang. Banyak ditemui dalam menyelesaikan soal bahasa Indonesia siswa mendapat nilai rendah dikarenakan tidak membaca dan memahami soal secara keseluruhan. Selama ini pembelajaran di kelas masih didominasi oleh guru dengan ceramah dan tugas ter- 
kadang diskusi kelompok dalam pertemuan terbatas.

Teks adekdot, yaitu teks yang berisi sebuah cerita lucu tentang orang terkenal yang dapat diambil pelajaran dari kisah tersebut. Teks anekdot memiliki kegiatan pembelajaran mengidentifikasi struktur atau bagian-bagian teks yang terdiri atas abtraksi, orientasi, krisis, reaksi, dan koda. Selanjutnya, siswa menyusun kembali teks anekdot dengan memperhatikan struktur lalu mempresentasikan, menanggapi, dan merevisi teks anekdot yang telah disusun, baik secara individu maupun kelompok.

Pengembangan ini menggabungkan dua model pembelajaran. Pertama, model pembelajaran kooperatif tipe Student Team Achievement Division (STAD). Model Pembelajaran Koperatif tipe $S T A D$ merupakan pendekatan Cooperative Learning yang menekankan pada aktivitas dan interaksi di antara siswa untuk saling memotivasi dan saling membantu dalam menguasai materi pelajaran guna mencapai prestasi yang maksimal. Kedua, model pembelajaran Make a Match. Model ini adalah pembelajaran mencari pasangan. Setiap siswa mendapat sebuah kartu (bisa soal atau jawaban), lalu secepatnya mencari pasangan yang sesuai dengan kartu yang ia pegang.

Berdasarkan permasalahan tersebut maka dapat dirumuskan masalah sebagai berikut. (1) Bagaimana pengembangan perencanaan model pembelajaran teks anekdot dengan STAD dan Make a Match?, (2) Bagaimana pengembangan materi ajar model pembelajaran teks anekdot dengan STAD dan Make a Match?, (3) Bagaimana pengembangan evaluasi model pembelajaran teks anekdot dengan STAD dan Make a Match?

Tujuan yang akan dicapai dalam penelitian ini sebagai berikut. (1) Untuk mengembangkan perencanaan model pembelajaran teks anekdot dengan STAD dan Make a Match. (2) Untuk mengembangkan materi ajar pengembangan model pembelajaran teks anekdot dengan STAD dan Make a Match. (3) Untuk mengembangkan evaluasi model pembelajaran teks anekdot dengan STAD dan Make a Match.

\section{TEORI}

Anekdot adalah kisah fiksi lucu pribadi seorang tokoh atau beberapa tokoh, yang benar-benar ada (Danandjaya, 1991:118). Dari pendapat Danan dapat diungkapkan bahwa anekdot merupakan kisah fiksi lucu pribadi tokoh terkenal yang benar-benar ada.

Keraf (2010:142) menyatakan anekdot adalah semacam cerita pendek yang bertujuan menyampaikan karakteristik yang menarik atau aneh mengenai seseorang atau suatu hal lain.

Dapat pula dikatakan anekdot adalah cerita singkat dan lucu yang digunakan untuk menyampaikan kritik melalui sindiran lucu terhadap kejadian yang menyangkut orang banyak atau perilaku tokoh publik. Menyampaikan kritik melalui anekdot menimbulkan reaksi dari pertentangan perasaan antara nyaman dan tidak nyaman, puas dan frustasi, serta tercapai atau gagal tetapi berujung pada pelajaran yang dapat diambil dari sebuah kejadian atau tokoh.

Fungsi komunikasi teks anekdot adalah untuk menyampaikan kritik terhadap kejadian yang menyangkut orang banyak atau perilaku tokoh publik. Kritik yang disampaikan bersifat menyindir secara halus agar orang yang bersangkutan dapat memahami dan memperbaiki kesalahan yang telah diperbuat.

Struktur teks anekdot adalah sebagai berikut. (1) Abstraksi adalah bagian awal paragraf yang berfungsi memberi gambaran tentang teks. Biasanya bagian ini menunjukkan hal unik yang akan ada di dalam teks. (2) Orientasi adalah bagian yang menunjukkan awal kejadian cerita atau latar belakang 
bagaimana peristiwa terjadi. Biasanya penulis bercerita dengan detali di bagian ini.

(3) Krisis adalah bagian yang menunjukkan terjadi hal atau masalah yang unik atau tidak biasa yang terjadi pada si penulis atau orang yang diceritakan. (4) Reaksi adalah bagian bagaimana cara penulis atau orang yang ditulis menyelesaikan masalah yang timbul di bagian krisis tadi. (5) Koda merupakan bagian akhir dari cerita unik tersebut. Bisa juga dengan simpulan tentang kejadian yang dialami penulis atau orang yang ditulis.

Strategi belajar kooperatif, belajar kolaboratif, dan belajar berbasis masalah merupakan perwujudan belajar dengan berinteraksi dengan orang lain. Bahkan kemampuan belajar seseorang dapat ditingkatkan dengan berinteraksi bersama orang lain (Vygotsky) dan khusus belajar untuk dewasa (andragogi) adalah bersifat selfdireted dan peran interaksi dengan sesama dan sumber belajar lain sangat menentukan keberhasilan belajar (Knowles dalam Sitepu, 2014:83).

Nurulhayati (dalam Rusman (2014: 203) menyebutkan bahwa pembelajaran kooperatif adalah strategi pembelajaran yang melibatkan siswa berpartisipasi dalam kelompok kecil untuk saling berinteraksi.

Di antara konsep penting bagi semua metode kelompok belajar siswa adalah kesempatan yang sama untuk berhasil. Hal ini berarti bahwa apa yang disumbangkan siswa untuk kelompok mereka berdasarkan pada kemajuan mereka atas kemampuan mereka sendiri sebelumnya. Hal ini menjamin bahwa anak-anak yang pintar, sedang, dan kurang pintar sama-sama tertantang untuk melakukan yang terbaik, serta peran serta dari semua anggota kelompok akan dinilai. (Sharan, 2014:4)

Pembelajaran kooperatif tipe Student Team Achievement Division (STAD) yang dikembangkan oleh Robert Slavin dan teman- temannya di Universitas John Hopkin (dalam Slavin, 1995) merupakan pembelajaran kooperatif yang paling sederhana, dan merupakan pembelajaran kooperatif yang cocok digunakan oleh guru yang baru mulai menggunakan pembelajaran kooperatif.

Student Team Achievement Division $(S T A D)$ adalah salah satu tipe pembelajaran kooperatif yang paling sederhana. Siswa ditempatkan dalam tim belajar beranggotakan empat sampai lima orang yang merupakan campuran menurut tingkat pengetahuan, jenis kelamin, dan suku. Guru menyajikan pelajaran, kemudian siswa bekerja dalam tim untuk memastikan bahwa seluruh anggota tim telah menguasai pelajaran tersebut. Akhirnya, seluruh siswa diberi kuis tentang materi itu. Pada saat mengerjakan kuis, mereka tidak boleh saling membantu.

Slavin (dalam Noornia, 1997:21) menyebutkan ada lima komponen utama dalam pembelajaran kooperatif model $S T A D$. Kelima komponen tersebut adalah: (1) penyajian kelas, (2) penetapan siswa dalam kelompok, (3) tes dan kuis, (4) skor peningkatan individual, dan (5) pengakuan kelompok.

Tahap pelaksanaan pembelajaran model STAD sebagai berikut. (1) Penyampaian tujuan dan motivasi. (2) Pembagian kelompok. (3) Presentasi dari guru. (3) Kegiatan belajar dalam satu tim (kerja tim). (4) Kuis. (5) Penghargaan Prestasi Tim. (Rusman, 2014:215-217)

Kelebihan pembelajaran model STAD sebagai berikut. (1) Siswa bekerja sama dalam mencapai tujuan dengan menjunjung norma-norma kelompok. (2) Siswa aktif membantu dan memotivasi semangat untuk berhasil bersama. (3) Aktif berperan sebagai tutor sebaya untuk lebih meningkatkan keberhasilan kelompok. (4) Interaksi antarsiswa seiring dengan peningkatan kemampuan mereka dalam berpendapat. (5) 
Meningkatkan kecakapan individu. (6) Tidak bersifat kompetitif. (7) Tidak memiliki rasa dendam.

Kekurangan pembelajaran model STAD adalah sebagai berikut. (1) Kontribusi dari siswa berprestasi rendah menjadi berkurang. (2) Siswa berprestasi tinggi akan mengarah pada kekecewaan karena peran anggota yang pandai lebih dominan. (3) Membutuhkan waktu yang lebih lama bagi siswa sehingga sulit mencapai target kurikulum. (4) Membutuhkan waktu yang lebih lama sehingga pada umumnya guru tidak mau menggunakan pembelajaran kooperatif. (5) Membutuhkan kemampuan khusus sehingga tidak semua guru dapat melakukan pembelajaran kooperatif. (6) Menuntut sifat tertentu dari siswa, misalnya suka bekerja sama (Aris,2016:189).

Model pembelajaran Make a Match merupakan model pembelajaran yang dikembangkan Loma Curran. Ciri utama model Make a Match adalah siswa diminta mencari pasangan kartu yang merupakan jawaban atau pertanyaan materi tertentu dalam pembelajaran. Pelaksanaan model Make a Match harus didukung dengan keaktifan siswa untuk bergerak mencari pasangan kartu yang sesuai dengan jawaban atau pertanyaan dalam kartu tersebut. Siswa yang pembelajarannya dengan model Make a Match aktif mengikuti pembelajaran dapat mempunyai pengalaman belajar yang bermakna (Aris, 2016: 98).

Kelebihan pembelajaran Make a Match menurut Aris (1) Suasana kegembiraan akan tumbuh dalam proses pembelajaran. (2) Kerja sama antar sesama siswa terwujud dengan dinamis. (3) Munculnya dinamika gotong-royong yang merata di seluruh siswa (Aris, 2016:99).

Kekurangan dapat ditemukan pembelajaran Make a Match menurut Aris (1) Diperlukan bimbingan dari guru untuk melakukan pembelajaran. (2) Suasana kelas menjadi gaduh sehingga dapat mengganggu kelas lain. (3) Guru perlu persiapan bahan dan alat yang memadai (Aris, 2016:99).

\section{METODE}

Metode pengembangan yang digunakan peneliti adalah metode penelitian dan

Pengembangan (Research and Development/R \& D). Research and Development adalah metode penelitian yang digunakan untuk menghasilkan produk tertentu, dan menguji keefektifan produk tersebut. (Sugiyono, 2013:297).

Model dalam tahap pengembangan ini dibagi menjadi dua, sebagai berikut. Pertama, model produk dalam penelitian pengembangan ini berupa petunjuk penggunaan pengembangan model pembelajaran teks anekdot dengan penggabungan STAD dan Make a Macth. Persiapan dengan pemberian instruksi, membagi kelompok dan lembar penilaian. Mengerjakan secara berkelompok membuat kartu soal dan jawaban. Melaksanakan tes kelompok dan tes individu dengan menggunakan kartukartu lalu mencocokkan antara kartu soal dengan jawaban. Selanjutnya memberi penghargaan kelompok. Kedua, model proses dalam pengembangan ini berupa model Dick \& Carey. Model Dick \& Carey terdiri atas sepuluh langkah, yaitu mengidentifikasi tujuan, melakukan analisis instruksional, mengidentifikasi tingkah laku awal atau karakteristik siswa, merumuskan tujuan performasi, mengembangkan butir tes acuan atau patokan, mengembangkan strategi pembelajaran, mengembangkan atau memilih pengajaran, merancang dan melaksanakan evaluasi formatif, menulis perangkat, dan revisi pengajaran (Dick \& Carey dalam Yamin, 2013:18)

Adapun subjek coba produk hasil pengembangan adalah uji ahli atau validasi. Hal ini dilakukan dengan responden para 
ahli perancangan model atau produk media, ahli bahasa, dan ahli materi. Kegiatan ini dilakukan untuk meninjau (mereview) produk awal dan memberikan masukan untuk perbaikan. Ahli materi dan bahasa pada tahap ini adalah instruktur provinsi ahli materi pengembangan kurikulum pembelajaran. Ahli media adalah instruktur nasional bidang kurikulum. Setelah mendapat penilaian dan masukan dari ahli uji. Selanjutnya, dilakukan uji coba pengembangan pembelajaran.

Subjek uji coba kelompok kecil pada tahap ini adalah dua puluh orang peserta didik kelas X SMA Negeri 2 Samarinda. Kedua puluh peserta didik tersebut terdiri atas sembilan laki-laki dan sebelas perempuan, tujuh peserta didik dengan katagori tinggi, sembilan peserta didik yang nilai dengan katagori sedang, empat peserta didik katagori rendah. Katagori tersebut dilihat dari perolehan nilai UN Bahasa Indonesia di SMP. Kedua puluh peserta didik terdiri atas suku, daerah, dan agama yang berbeda.

Tahap uji lapangan atau kelompok besar terdiri atas 32 orang siswa dan seorang guru bahasa Indonesia kelas X SMA Negeri 2 Samarinda. Penilaian instrumen total dilakukan dari jumlah skor yang diperoleh lalu dibagi dengan jumlah skor total. Kemudian, hasilnya dikalikan dengan banyaknya pilihan jawaban.

Jenis data yang dikumpulkan melalui pelaksanaan evaluasi dikelompokkan menjadi tiga bagian, yaitu: (1) data evaluasi tahap pertama berupa uji hasil para ahli materi pengembangan kurikulum pembelajaran, (2) data evaluasi tahap kedua berupa data hasil uji coba kelompok kecil, dan (3) data uji coba lapangan atau kelompok besar berupa data hasil tinjauan (review) peserta didik tingkat $X$ dan guru bahasa Indonesia tingkat X. Seluruh data yang diperoleh disebut data kualitatif.
Data kualitatif diperoleh dari hasil tinjauan (review) ahli materi pengembangan pembelajaran melalui angket tanggapan (format A), hasil review ahli pengembangan pembelajaran (format B), hasil review uji perorangan atau kelompok kecil (format C) dan hasil review siswa dan guru melalui angket tanggapan (format D dan E). Data kualitatif diperoleh juga melalui wawancara terhadap subjek uji coba.

Instrumen yang digunakan untuk mengumpulkan data dalam penelitian pengembangan pembelajaran ini adalah angket dan pedoman wawancara. Angket dalam penelitian ini terdiri atas angket uji ahli berupa instrumen validasi ahli materi/praktisi, ahli bahasa, ahli media, angket uji perseorangan atau kelompok kecil, angket uji lapangan atau kelompok besar, dan angket uji daya tarik.

Instrumen kelayakan model pembelajaran menggunakan skala Likert dengan alternatif jawaban: sangat baik, baik, cukup, kurang, dan sangat kurang. Supaya dapat diperoleh data kuantitatif maka alternatif jawaban diberi skor yakni sangat baik $=5$, baik $=4$, cukup $=3$, kurang $=2$, dan sangat kurang $=1$.

Angket ini digunakan kepada perserta didik untuk mengetahui respons mereka terhadap pengembangan model pembelajaran STAD dan Make a Match. Pemberian skor berdasarkan pada skala Likert dengan rentang 1-5.

Teknik analisis data yang digunakan adalah teknik analisis data deskriptif kualitatif. Teknik ini digunakan untuk memberikan gambaran bagaimana mengolah data. Hasil review didapat dari ahli materi, bahasa, media, respons siswa, dan guru bahasa Indonesia kelas X. Teknik analisis data ini dilakukan dengan mengelompokkan informasi-informasi dari data kualitatif yang berisi masukan, kritik, dan saran perbaikan yang terdapat pada angket dan hasil wawan- 
cara. Kemudian, hasil analisis ini digunakan untuk merevisi produk pengembangan model pembelajaran.

Analisis statistik deskriptif digunakan untuk mengolah data yang diperoleh melalui angket dalam bentuk deskripsi persentase. Rumus yang digunakan untuk menghitung persentase dari masing-masing subyek adalah (Sugiono,2016:442):

Presentase $=\underline{\Sigma(\text { jawaban } \times \text { bobot tiap pilihan })} \times 100$ $\mathrm{N} \times$ bobot tertinggi

\section{PEMBAHASAN}

Pengembangan bahan ajar ini terdiri atas pendahuluan, desain draf dan pembuatan produk awal berupa desain perangkat, uji coba terbatas, validasi awal, revisi dan uji coba lapangan, evaluasi dan revisi, validasi akhir, dan pembuatan laporan pengembangan.

Hasil uji ahli materi menilai beberapa indikator, yaitu: bahasa, perencanaan, kelayakan isi/materi, kelayakkan penyajian, dan kelayakan evaluasi. Perolehan penilaian pada tahap uji coba 67 dari skor maksimal 88 menghasilkan presentase $67 / 88 \times 100=$ $76 \%$ dengan kualifikasi layak dan dapat diimplementasikan. Perolehan penilaian pada tahap uji coba lapangan 75 dari skor maksimal 88 menghasilkan presentase 75/ $88 \times 100=85 \%$ dengan sangat layak dan dapat diimplementasikan.

Hasil ahli bahasa menilai beberapa indikator, yaitu: lugas, komunikatif, dialog dan interaktif, kesesuaian dengan perkembangan peserta didik, dan kesesuaian dengan kaidah bahasa. Perolehan penilaian pada tahap uji coba adalah 33 dari skor maksimal 36. Skor ini menghasilkan presentase $33 / 36 \times 100=91 \%$ dengan kualifikasi sangat layak dan dapat diimplementasikan. Perolehan penilaian pada tahap uji coba lapangan, 35 dari skor maksimal 36 menghasilkan presentase $35 / 36 \times 100=97 \%$ dengan sangat layak dan dapat diimplementasikan.

Ahli media menilai beberapa indikator, yaitu: kesederhanaan, kemenarikkan, keterpaduan, penekanan, dan keseimbangan. Perolehan penilaian pada tahap uji coba 56 dari skor maksimal 60 menghasilkan presentase 56/60x100=93 \% dengan kualifikasi sangat layak dan dapat diimplementasikan. Perolehan penilaian pada tahap uji coba lapangan 58 dari skor maksimal 60 menghasilkan presentase 58/60×100=96\% dengan sangat layak dan dapat diimplementasikan.

KEKAPITULASI IALWASI TII AHLI

\begin{tabular}{|c|c|c|c|c|c|c|c|c|}
\hline \multicolumn{2}{|c|}{ Judul Pengembangan } & \multicolumn{3}{|c|}{$\begin{array}{l}\text { Pengembangan Pembelajaran Teks } \\
\text { Kelas X SMA }\end{array}$} & \multicolumn{4}{|c|}{ an Model STAD dan Make A Match pada Siswa } \\
\hline \multirow[t]{2}{*}{ No } & \multirow[t]{2}{*}{ Valodator:Tim Ahli } & \multirow[t]{2}{*}{ Kategori Validasi } & \multicolumn{2}{|c|}{$\begin{array}{c}\text { Jumlah } \\
\text { Nilai }\end{array}$} & \multicolumn{2}{|c|}{ Presentase } & \multicolumn{2}{|c|}{ Kualifikasi dan Tidak Lanjut } \\
\hline & & & 1 & 2 & 1 & 2 & 1 & 2 \\
\hline 1. & $\begin{array}{l}\text { Ahli Materi } \\
\text { Atik Sri Rahayu, } \\
\text { M.Pd }\end{array}$ & $\begin{array}{l}\text { (bahasa: perencanaan, } \\
\text { kelayakan isi materi: } \\
\text { kelayakkan penyajian, } \\
\text { dan kelayakan } \\
\text { evaluasi) }\end{array}$ & 67 & 75 & $\begin{array}{l}6788 \times 100 \\
=76 \%\end{array}$ & $\begin{array}{l}7588 \times 100 \\
=85 \%\end{array}$ & $\begin{array}{l}\text { layak dan dapat } \\
\text { dimplementasikan }\end{array}$ & $\begin{array}{l}\text { sangat layak dan } \\
\text { dapat } \\
\text { diimplementasikan }\end{array}$ \\
\hline 2. & $\begin{array}{l}\text { Ahli Bahasa } \\
\text { Rus Suharto, S.Pd. } \\
\text { M.Pd }\end{array}$ & $\begin{array}{l}\text { lugas, komunikatif, } \\
\text { dialog dan interaktif: } \\
\text { kesesuaian dengan } \\
\text { perkembangan peserta } \\
\text { didik, dan kesesuaian } \\
\text { dengan kaidah bahasa. }\end{array}$ & 33 & 35 & $\begin{array}{l}33: 36 \times 100 \\
=91 \%\end{array}$ & $\begin{array}{l}3536 \times 100 \\
=97 \%\end{array}$ & $\begin{array}{l}\text { sangat layak dan } \\
\text { dapat } \\
\text { diimplementasikan }\end{array}$ & $\begin{array}{l}\text { sangat layak dan } \\
\text { dapat } \\
\text { diimplementasikan }\end{array}$ \\
\hline 3. & \begin{tabular}{|l} 
Ahli Media \\
Dr. Hendro \\
Kuncoro, M.Pd
\end{tabular} & $\begin{array}{l}\text { kesederhanaan, } \\
\text { kemenarikkan, } \\
\text { keterpaduan. } \\
\text { penekanan, dan } \\
\text { keseimbangan. } \\
\end{array}$ & 56 & 58 & $\begin{array}{l}56: 60 \times 100 \\
=93 \%\end{array}$ & $\begin{array}{l}58: 60 \times 100 \\
=96 \%\end{array}$ & $\begin{array}{l}\text { sangat layak dan } \\
\text { dapat } \\
\text { dimplementasikan }\end{array}$ & $\begin{array}{l}\text { sangat layak dan } \\
\text { dapat } \\
\text { dimplementasikan }\end{array}$ \\
\hline
\end{tabular}


xHasil uji coba lapangan dalam skala terbatas mengunakan kelas X MIPA 1 dengan jumlah 20 siwa terdiri atas 3 kelompok. Setiap kelompok terdiri atas 67 orang siswa. Selanjutnya, melakukan langkah-langkah Model Pengembangan Pembelajaran Teks Anekdot dengan STAD dan Make a Match.

Hasil pengumpulan dan analisis data diperoleh dengan cara wawancara, observasi dan angket. Siswa mengerjakan soal tertulis 15 pilihan ganda sebagai pengetahuan awal terhadap teks anekdot. Nilai tertinggi 80 dan terendah 73 dengan rata-rata nilai 78. Kegiatan selanjutnya adalah penyampaian materi anekdot melalui LCD. Melakukan tanya jawab secara tidak langsung melakukan wawancara tidak terstruktur. Hasil yang diperoleh semua kelompok adalah nilai 100. Selanjutnya, melakukan wawancara lisan secara individu. Dari kegiatan ini diperoleh nilai dengan hasil 19 siswa mendapat 100 dan 1 orang siswa mendapat 80. Hasil tes akhir (post test) diperoleh nilai tertinggi 100 dan terendah 80 dengan rata-rata 89.

Uji lapangan dalam skala besar mengunakan kelas X MIPA 5 dengan jumlah 36 siwa terdiri atas 6 kelompok setiap kelompok terdiri atas 6 orang siswa. Selanjutnya, melakukan langkah-langkah Pengembangan Pembelajaran Teks Anekdot dengan Model STAD dan Make a Match.

Hasil pengumpulan dan analisis data diperoleh dengan cara wawancara, observasi, dan angket. Hasil pembelajaran pada tes awal (pre test) menggunakan 15 soal pilihan ganda dengan hasil nilai tertinggi 93 dan nilai terendah 73. Berdasarkan perolehan nilai tersebut dibuatlah kelompok secara heterogen pengetahuan, dilanjutkan jenis kelamin, agama, dan suku. Kegiatan selanjutnya adalah penyampaian dan video materi anekdot melalui LCD. Berikutnya melakukan tanya jawab yang secara tidak langsung melakukan wawancara tidak terstruktur.

Hasil yang diperoleh oleh 6 kelompok adalah nilai 100. Secara lisan dan individu dengan hasil 35 siswa mendapat nilai 100 dan seorang siswa mendapat nilai 80. Pertemuan selanjutnya pada tanggal 20 September 2017 mengadakan post test dengan memberikan 15 soal pilihan ganda. Hasil yang diperoleh adalah nilai tertinggi 100 dan nilai terendah 80 dengan nilai rata-rata 93.

Hasil respons guru berdasarkan indikator penilaian kemudahan, keaktifan, keterampilan, ketertarikan, meningkatkan kemampuan, bekerja sama, dan kemandirian siswa dalam mengidentifikasi teks anekdot, perolehan hasil 31 skor maksimal 32 dengan hasil presentase $31 / 32 \times 100=96 \%$. Presentase keseluruhan subyek 96:1x $100 \%=96 \%$.

Hasil respons dari kelompok uji coba kelas X MIPA 1 berjumlah 20 orang. Para siswa memberikan respons berdasarkan indikator kemudahan, keaktifan, keterampilan, ketertarikan, meningkatkan kemampuan, bekerja sama, dan kemandirian siswa dalam mengidentifikasi teks anekdot. Perolehan hasil 605 dengan skor maksimal 640 dengan nilai presentasi subjek $96 \%$. Perolehan presentase keseluruhan subjek 1886: $20 \times 100 \%=94 \%$.

Hasil respons dari kelompok uji coba kelas X MIPA 5 berjumlah 36 orang. Para siswa memberikan respons berdasarkan indikator kemudahan, keaktifan, keterampilan, ketertarikan, meningkatkan kemampuan, bekerja sama, dan kemandirian siswa dalam mengidentifikasi teks anekdot. Perolehan hasil 1121 dengan skor maksimal 1152 dengan nilai presentasi subjek $97 \%$. Perolehan presentase keseluruhan subjek $3491: 36 \times 100 \%=97 \%$. 
REKAPITULASI RESPON GURU DAN SISWA

Judul Pengembangan: Pengembangan Pembelajaran Teks Anekdot dengan Model STAD dan

Make A Match pada Siswa Kelas X SMA

\begin{tabular}{|c|c|c|c|c|c|}
\hline No & Responden & $\begin{array}{c}\text { Jumlah } \\
\text { Responden }\end{array}$ & $\begin{array}{c}\text { Jumlah Nilai } \\
\text { Subvek }\end{array}$ & $\begin{array}{c}\text { Presentase } \\
\text { Keseluruhan } \\
\text { Subyek }\end{array}$ & Kualifikasi \\
\hline 1. & $\begin{array}{l}\text { Guru Mapel } \\
\text { bahasa Indonesia } \\
\text { Hj. Widijarty= S.Pd }\end{array}$ & 1 guru & $\begin{array}{l}\Sigma N \mathrm{~N} \times 100 \\
=31: 32 \times 100 \\
=96 \%\end{array}$ & $\begin{array}{l}=F: N) \times 100 \% \\
=96: 1 \times 100 \% \\
=96 \%\end{array}$ & Sangat Baik \\
\hline 2. & $\begin{array}{l}\text { Kelompok Uji } \\
\text { Coba } \\
\text { X MIPA } 1\end{array}$ & 20 siswa & $\begin{array}{l}\Sigma \mathrm{N} \times 100 \\
=605: 640 \times 100 \\
=94 \%\end{array}$ & $\begin{array}{l}=(\mathrm{F}: \mathrm{N}) \times 100 \% \\
=1886: 20 \times 100 \% \\
=94 \%\end{array}$ & Sangat Baik \\
\hline 3. & $\begin{array}{l}\text { Kelompok Besar' } \\
\text { Uji lapangan } \\
\text { X MIPA } 5\end{array}$ & 36 siswa & $\begin{array}{l}\Sigma N \times 100 \\
=1121: 1152 \times 100 \\
97 \%\end{array}$ & $\begin{array}{l}=(F: N) \times 100 \% \\
=3491: 36 \times 100 \% \\
=97 \%\end{array}$ & Sangat Baik \\
\hline
\end{tabular}

Materi ajar berupa bahan ajar Model Pembelajaran Teks Anekdot dengan STAD dan Make A Match menyajikan tiga tahapan pembelajaran sebagai berikut.

Tahap pendahuluan

- Guru memberikan tes awal (pre test) secara tertulis dengan memberikan 15 soal pilihan ganda tentang materi yang belum dipelajari.

- Guru memberikan motivasi agar siswa tertarik pada materi yang akan mereka terima.

- Guru membentuk siswa ke dalam kelompok yang heterogen (jenis kelamin, suku, pengetahuan, dan agama).

- Menyosialiasakan kepada siswa tentang model pembelajaran yang digunakan dengan tujuan agar siswa mengenal dan memahaminya.

- Guru memberikan apersepsi yang berkaitan dengan materi yang akan dipelajari.

- Guru menyampaikan materi teks anekdot melalui salindia (power point) dan video dengan menggunakan LCD.
- Guru melakukan tanya jawab tentang materi teks anekdot.

- Guru membuat potongan struktur teks anekdot dan potongan cerita anekdot secara acak, lalu siswa mencari pasangan kartu yang mereka pegang.

Tahap Pengembangan

- Guru meminta siswa secara berkelompok untuk mencari contoh teks anekdot di internet.

- Siswa secara berkelompok membuat kartu yang berisi soal (struktur teks anekdot) dan kartu jawaban (teks anekdot) menaruhnya dalam amplop yang telah disediakan sebelumnya.

Guru memantau kerja dari tiap kelompok dan membimbing siswa yang mengalami kesulitan.

Siswa secara bergiliran membacakan hasil kerja kelompok mereka, sedangkan kelompok lain mendengarkan cerita dan pasangan struktur teks anekdot yang dibacakan. 
- Guru mengumpulkan amplop yang telah selesai dikerjakan untuk menjadi tes.

\section{Tahap Penerapan}

- Guru membagikan amplop kepada kelompok yang berbeda untuk diselesaikan secara berkelompok.

- Siswa mempresentasikan jawaban di depan kelas dan melakukan penilaian bersama.

- Selanjutnya, siswa mengerjakan amplop secara individu. Karena terbatasan amplop, guru meminta 5 orang pertama. Siswa yang mendapat nilai 100 boleh untuk mengadakan evaluasi.

- Selanjutnya, memberi penilaian di bawah bimbingan guru.

- Selanjutnya, guru melakukan tes akhir (post test) dengan menggunakan 15 soal pilihan ganda.

- Guru menginput nilai dan mengumumkan perolehan kelompok yang miliki nilai terbaik.

- Guru memberikan hadiah berupa buku novel yang merupakan the best seller.

\section{PENUTUP}

Berdasarkan hasil pengembangan dan pembahasan, simpulan yang didapat adalah Pengembangan perencanaan, materi ajar, dan evaluasi pada pembelajaran teks anekdot dengan model STAD dan Make A Match pada kelas X SMA sudah memenuhi standar. Hal ini diperoleh setelah melalui validasi uji ahli materi, uji ahli bahasa, uji praktisi pendidikan dan uji ahli media dengan perolehan nilai rata-rata 92 dengan kriteria kualifikasi sangat layak atau sangat baik.

Hasil belajar siswa kelompok uji coba sangat baik dengan nilai pengetahuan individu rata-rata 89, nilai keterampilan individu rata-rata 99, dan nilai keterampilan kelompok seluruhnya mendapat 100. Hasil belajar siswa kelompok uji lapangan sangat baik dengan nilai pengetahuan individu rata-rata 93, nilai keterampilan individu rata-rata 99, dan nilai keterampilan kelompok seluruhnya mendapat 100 . Nilai respons guru diperoleh presentase $96 \%$, respons siswa kelompok uji coba $94 \%$, dan respons siswa kelompok uji lapangan $97 \%$ terhadap pembelajaran melalui angket dengan kualifikasi sangat baik digunakan pada pembelajaran di kelas.

Berdasarkan simpulan dalam pengembangan ini perlu diajukan saran-saran sebagai berikut.

1. Guru, perlu menggunakan berbagai model pembelajaran yang telah diteliti sebelumnya dengan memodifikasi menjadi pengembangan pembelajaran yang menyenangkan dan memudahkan dalam memahami materi yang disampaikan. Pembelajaran yang menyenangkan akan membuat para peserta didik ikut serta aktif dalam mencapai tujuan belajar yang bermakna. Hasil pengembangan ini dapat digunakan untuk menambah salah satu reverensi guru-guru bahasa Indonesia dalam mengembangkan pembelajaran teks anekdot, khususnya untuk memudahkan mengidentifikasi struktur teks.

2. Kepala Sekolah, hendaknya terus selalu mendukung kegiatan penggunaan berbagai model pembelajaran dengan berbagai modifikasi atau variasi agar pembelajaran di dalam kelas lebih bermakna. Kepala sekolah membantu guru dalam menyediakan sarana belajar dengan menambah buku-buku pelajaran, perbaikan LCD, serta terus mengadakan pelatihan pengembangan guru dalam mengolah kelas dan pelajaran yang diampunya.

3. Pengembang pembelajaran selanjutnya, agar dapat menemukan model pembelajaran yang lebih baik dalam meng- 
identifikasi struktur teks anekdot sehingga siswa-siswa dapat memahami teks dengan suasana belajar yang nyaman, menyenangkan, membuat mereka lebih aktif dalam pembelajaran teks anekdot, serta dapat mencapai tujuan pembelajaran, yaitu memahami struktur teks anekdot dengan sangat baik.

\section{DAFTAR PUSTAKA}

Aris, Shoimin. 2016. 68 Model Pembelajaran Inovatif dalam Kurikulum. 2013. Yogyakarta: Ar-Ruzz Media.

Arikunto, S. 2002. Dasar-dasar Evalusi Pendidikan. Jakarta: Bumi Aksara.

Arikunto, suharsimin. 1996. Prosedur Penelitian, Suatu Pendekatan Praktek. Jakarta: Bumi Aksara.

Danandjaja, James.1991. Foklor Indonesia . Jakarta: Pustaka Utama Grafiti.

Kementerian Pendidikan dan Kebudayaan, 2013. Permendikbud No 54 tentang Standar Kompetensi Pendidikan Dasar dan Menengah. Jakarta: Kementerian Pendidikan dan Kebudayaan.

Kementerian Pendidikan dan Kebudayaan. 2014. Bahasa Indonesia Ekspresi Diri dan Akademik SMA Kelas X. Jakarta: Kementerian Pendidikan dan Kebudayaan.

Kementerian Pendidikan dan Kebudayaan. 2016. Bahasa Indonesia SMA Kelas X. Jakarta: Kementerian Pendidikan dan Kebudayaan.

Kementerian Pendidikan dan Kebudayaan, 2016. Silabus Mata Pelajaran Sekolah Menengah Atas/Madrasah Aliyah/Sekolah Menengah Kejuruan/Madrasah Aliyah Kejuruan (SMA/MA/SMK/MAK) Mata Pelajaran Bahasa Indonesia. Jakarta: Kemendikbud.

- - - - - - - - - - - 2017. Silabus Mata Pelajaran Sekolah Menengah Atas/ Madrasah Aliyah/Sekolah Menengah
Kejuruan/Madrasah Aliyah Kejuruan (SMA/MA/SMK/MAK) Mata Pelajaran

Bahasa Indonesia. Jakarta: Kemendikbud. Keraf, Gorys.2010. Argumentasi dan Narasi. Jakarta: PT Gramedia Pustaka Utama.

Moleong, Lexy J.2014. Metodologi Penelitian Kualitatif. Bandung: PT. Remaja Rosdakarya.

Noorniah.1997.Penerapan pembelajaran

Kooperatif dengan Metode STAD pada

Pengajaran Persen Kelas VI SD Ma'Arif02

Singosari. Malang: Program

Pascasarjana Universitas Negeri Malang.

Nurgiyanto, Burhan. 2014. Penilaian

Pembelajaran Bahasa Berbasis Kompetensi.

Yogyakarta: BPFE-Yogyakarta.

Purwanto, 2011. Evaluasi Hasil Belajar. Yogyakarta: Pustaka Belajar.

Rohman, Muhammad dan Sofan Amri. 2013.

Strategi dan Desain Pengembangan Sistem

Pembelajaran. Jakarta: Prestasi

Pustakaraya.

Rusman. 2014. Model-Model Pembelajaran.

Jakarta: PT. Rajagrafindo Persada.

Sanjaya, Wina. 2008. Perencanaan dan Desain

Sistem Pembelajaran. Jakarta: Kencana.

Sharan, Shlomo. 2014. The Handbook of Cooperative Learning "Inovasi Pengajaran dan Pembelajaran untuk Memicu Keberhasilan Siswa di Kelas". Yogyakarta: Istana Media.

Sitepu. 2014. Pengembangan Sumber Belajar. Jakarta: PT. Rajagrafindo Persada.

Sugiyono. 2013. Metode Penelitian Pendidikan, Pendidikan Kuantitatif, Kualitatif, dan RED. Bandung: Alfabeta. 2010. Metode Penelitian Pendidikan. Jakarta: Alfabetha. 2016. Metode Penelitian \& Pengembangan. Bandung: Alfabetha.

Trianto. (2011) .Model-model pembelajaran inovatifberorientasi konstruktivitis. Jakarta: Prestasi Pustaka. 
Wiguna, Guntur. 2014. Koleksi Humor Gus Dur. Jakarta: Narasi.

Yamin, Martinis. 2013. Strategi\&Metode dalam Model Pembelajaran. Jakarta: Referensi (GP Press Group). 